\title{
What if Online Students Take on the Responsibility: Students' Cognitive Presence and Peer Facilitation Techniques
}

\author{
Ye Chen \\ University of Alaska Southeast \\ Jing Lei and Jiaming Cheng \\ Syracuse University
}

\begin{abstract}
The purpose of this study was to investigate the characteristics of online students' cognitive presence in a peer-facilitated discussion environment, and to identify the peer facilitation techniques that can enhance cognitive presence development. In this study, 738 discussion messages were examined by both qualitative and quantitative content analysis. It was revealed that although cognitive presence was detected in most discussion messages, it was exhibited at a relatively lower level. The involvement of peer facilitators was found to correlate with students' higher-level cognitive presence. It was found that asking initiating questions of a specific type by peer facilitators can positively affect the level of cognitive presence. In addition, a variety of the peer facilitation techniques were systematically studied to identify their effects on students' cognitive presence.
\end{abstract}

Keywords: Cognitive presence, peer facilitation, online instruction, discussion

Chen, Y., Lei, J., \& Cheng, J. (2019). What if online students take on the responsibility: students' cognitive presence and peer facilitation techniques. Online Learning, 23(1), 3761. doi:10.24059/olj.v23i1.1348

\section{What if Online Students Take on the Responsibility: Students' Cognitive Presence and Peer Facilitation Techniques}

Since cognitive presence represents the level of students' engagement in learning, it is an important indicator of the quality of online education (Garrison et al., 2003). Garrison et al. (2001) defined cognitive presence as "the extent to which learners are able to construct and confirm meaning through sustained reflection and discourse" (p. 11). To design a lesson that stimulates rich cognitive presence, it is important to understand the characteristics of students' cognitive presence and the practices that support cognitive presence development.

Providing facilitation is a strategy to promote cognitive presence (Garrison et al., 2003). Numerous studies have investigated the facilitative role of instructors in supporting students' online learning (e.g., Gerber, et al., 2005; Guo, et al., 2014; Mazzolini, et al., 2003; Rovai, 2007). However, some scholars have expressed concern about making the instructor the sole provider of 
facilitation (Hew, 2015). One concern is that the instructor's "authoritarian presence" may oppress students' thoughts and voices (Rourke \& Anderson, 2002, p. 4). Students tend to take the instructor's statements as the authoritarian answer (Fauske \& Wade, 2003). Some even feel nervous in expressing their thoughts and feelings when the instructor is present (Hew, et al., 2010). Also, they might consider instructors' questions as a form of assessment (Mazzolini \& Maddison, 2003). This may further increase their hesitation to express themselves. Another concern is the high demand of time and energy for facilitating an active and asynchronous online class (Hew, 2015). Facilitating is like being a parent who is "on duty all the time" in an asynchronous class (Hew, 2015; Hiltz, 1988, p.441). Especially when the class size is large, challenges then arise.

Peer facilitation has been suggested as a way to share the leadership role with students (Poole, 2000). According to Kennedy (2004, p.753), peer facilitation is a method to auto-facilitate a learning system where "each individual member of the group exercises to some degree the leadership skills that enable the maturation process as a whole." In this process, students' diverse expertise creates a proximal zone of development, and this makes the facilitation possible (Baran \& Correia, 2009; Kennedy \& Kennedy, 2010). Students can also benefit from the facilitator role by gaining the hands-on experience of facilitating peers' learning (Hew, 2015). This can also help increase metacognitive awareness of their own learning (Garrison \& Akyol, 2015; Poole, 2000).

We posit that our knowledge of instructor facilitation is limited in interpreting the dynamics of peer facilitation. Chan et al. (2009) pointed out that the mechanism of peer facilitation is fundamentally different from that of instructor facilitation. This is because peer facilitation grows out of a lateral relationship while instructor facilitation is based on a hierarchical relationship (Chan et al., 2009; Zhao \& McDougall, 2005).

Research on peer facilitation is needed. Understanding peer facilitation can increase support to student facilitators, especially those who have limited domain knowledge and facilitation skills (Choi, et al., 2005). According to Onah, et al. (2014), the lack of pedagogical understanding of facilitation is the main cause of the lower completion rate in student-facilitated online classes. However, compared to the extensive studies on instructor facilitation, relatively few have investigated peer facilitation (Hew \& Cheung, 2011; Ng, et al., 2012). The existing studies on peer facilitation have made limited attempts to clearly delineate the specific facilitation techniques that can improve students' intellectual engagement (Hew \& Cheung, 2008; Hew \& Cheung, 2011; Ng, et al., 2010). The gap has been recognized by scholars who have argued that peer facilitation deserves more research attention (e.g. Baran \& Correia 2009; Chan, et al., 2009; Gašević, et al., 2015; Hew, 2015; Ng, et al., 2012).

This study explored students' cognitive presence in peer-facilitated online discussions and investigated the facilitation techniques used by student facilitators. By analyzing the discussion transcripts, we examined the following research questions:

1) What phases of cognitive presence are exhibited by students in the peer-facilitated online discussion? Are there any characteristics and patterns?

2) Does peer facilitation affect students' cognitive presence? Do different types of initiating questions affect students' cognitive presence differently?

3) What facilitation techniques are used by untrained peer facilitators? Can these techniques affect students' cognitive presence? 


\section{Review of Related Literature}

\section{Cognitive Presence}

Garrison et al. (2001) developed a Practical Inquiry (PI) model based on Dewey's work on reflection process. As illustrated in Figure 1, this model described the process of developing cognitive presence in four phases: Triggering event, Exploration, Integration, and Resolution. Triggering event is the initiating stage. At this stage, students may explicitly express their feelings of struggle or attempt to locate and describe the problem. The second phase is Exploration. Students explore various resources and generate possible explanations or solutions. Common activities include brainstorming, information searching, and idea exchange. In Exploration, the information is simply collected, shared, and stored in a fragmented way, and students do not identify the relationships hidden in or among pieces of the information. The third phase is Integration. Students start to make sense of the information they have obtained by identifying relationships. Activities at this phase include comparing, contrasting, connecting, synthesizing, logical reasoning, elaborating, or explaining. The fourth phase is Resolution. This phase tests, through observation or experiment, the effectiveness of a solution/hypothesis in the real world.

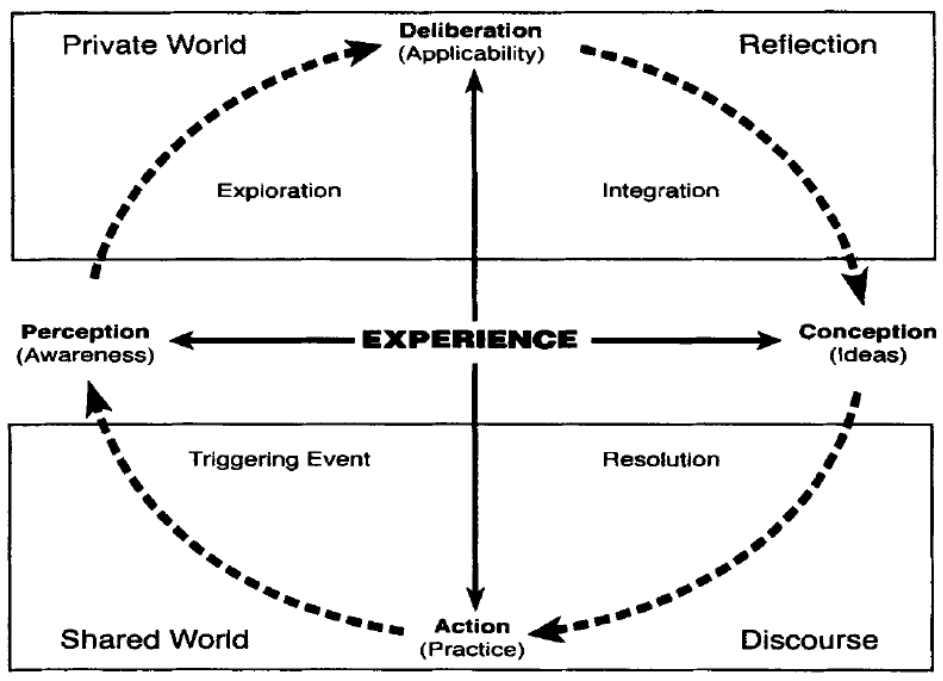

Figure 1. The practical inquiry framework (Garrison et al., 2000)

The PI model has been widely applied in analyzing various higher order thinking, such as critical thinking (de Leng et al., 2009), shared understanding (Stein et al., 2007), knowledge building (Celentin, 2007; Schrire, 2006), understanding construction (Koh et al., 2010), and complex cognitive task performance (Morueta et al., 2016). In recent years, the PI model has been increasingly used to examine students' learning in various environments. The studied learning environments include forum discussions in online courses (Yang, 2016; Zhao \& Sullivan, 2017), informal online learning communities (Sun, et al., 2017), public social media (Keles, 2018), mobile and flipped learning (Wu, et al., 2017), voice-recorded reflections (Taddei \& Budhai, 2016), blog conversations (Asoodar et al., 2014; Popescu, 2016), video gaming communities (Truong, 2017), and 3D virtual reality (McKerlich et al., 2011; Pellas \& Kazanidis, 2012).

\section{Facilitation of Cognitive Presence}

Several attempts have been made to study the facilitation of cognitive presence. These studies explored the use of different facilitation methods, such as the use of experts (Kanuka et al., 2007), roles (Darabi et al., 2011; Kalelioglu \& Gülbahar, 2014; Olesova et al., 2016), debate topics (Darabi et al., 2011; Kanuka et al., 2007; Richardson et al., 2010), cases and stories (Richardson 
et al., 2010), brainstorming (Kalelioglu \& Gülbahar, 2014), visual representation tools (Wang \& Shan, 2018), think aloud methods and technologies (Beach \& Willows, 2017), and reflection practice (Kanuka et al., 2007; Taddei \& Budhai, 2016).

Peer facilitation has also been recommended as a promising strategy to enhance cognitive presence (Garrison, 2003; Garrison \& Akyol, 2013; Shea, et al., 2014). Although early studies on cognitive presence emphasized the leadership role of teachers, Garrison et al. (2000) acknowledged that this role can be "performed by anyone in a community of inquiry" (p. 89). They later found that students were more involved in self-regulating their cognitive presence when a formal instructor was not present (Garrison \& Akyol, 2015). Wang and Shan's 2018 study revealed that such self-regulation can positively affect students' cognitive presence level. To facilitate students' engagement in online learning, Garrison and Akyol (2013) encouraged letting students take the lead. They commented that "each participant not only has the responsibility to construct personal meaning but assume the role and responsibility to facilitate and direct that process individually and collaboratively...Without these co-responsibilities we simply do not have a community of learners" (p.85).

\section{Peer Facilitation}

The term "peer facilitation" has its origins in the context of school counseling (Anderson, 1976; Gumaer, 1973). Gumaer (1973) defined peer facilitation as the behaviors and skills "to begin a small group discussion and to use the facilitating responses of clarifying, reflecting, and giving feedback" (p.4).

A number of studies have reported the practice of peer facilitation in online learning. According to Kear (2004), peer facilitation can naturally take place in online discussion even without an instructor's intervention. Ioannou, et al. (2014) studied this naturally-emerged peer facilitation. More researchers implemented peer facilitation by formally assigning facilitative roles (e.g., Hew \& Cheung, 2008; Ng, et al., 2010; Xie \& Ke, 2011). Most of these studies reported positive results. For example, when peer facilitated, overall participation in discussion increased (Poole, 2000), students posted more and higher-quality posts (Seo, 2007), and the participation of student facilitators changed significantly in terms of quantity, diversity, and interaction attractiveness (Xie, et al., 2014).

\section{Peer Facilitation Techniques}

McLuckie and Topping (2004) pointed out that identifying peer facilitation techniques and providing support in using these techniques is important to improve the quality of peer facilitation and student learning. Several studies have explored the facilitation techniques used by peer facilitators. Choi et al. (2005) proposed a peer-questioning framework to guide facilitators' questioning behaviors. Based on Salmon's e-moderating model in 2000, De Smet et al. (2008) proposed several techniques that can be used in different facilitation stages. More researchers identified the peer facilitation techniques through analyzing students' online discussion transcripts (e.g. Baran \& Correia, 2009; Chan et al., 2009; Ng, et al., 2010), or examined the use of facilitation techniques in student groups that achieved better performance (Hew \& Cheung, 2008; Hew \& Cheung, 2011; Lim, et al., 2011; Ng et al., 2012). Below, we discussed the particular peer facilitation techniques.

Questioning. In class discussion, a facilitator's contribution largely comes from the questioning behaviors (Chi, et al., 2001). The questions can be an important indicator of the quality of facilitation (Carlsen, 1993). Asking questions has also been reported as an effective peer facilitation technique (Chan et al., 2009; Choi et al., 2005; De Smet et al., 2008; Ng, et al., 2010; 
Hew \& Cheung, 2008; Lim, et al., 2011; Ng et al., 2012). Some facilitative questions that help develop students' thinking have been identified. These questions ask for explanation of how and why (Graesser, et al., 2002), for evidence drawn from life experience (Winne, 1979), and for evaluation of joint understanding (Hmelo-Silver \& Barrows, 2008).

Making clarification. Making clarification is a technique that explains why and how and elaborates by "adding details, giving examples, generating images, and in general relating the new material to what is already known" (King, 2007, p.21; Gao, 2013). This is also a commonly used peer facilitation technique in online discussion (De Smet et al., 2008; Lim, et al., 2011; Ng et al., 2012). To make a clarification more effective, a number of strategies, such as giving analogies (Capon \& Kuhn, 2010; Duit, et al., 2001; Gentner \& Gentner, 1983; Glynn, 1989), providing examples (Atkinson, et al., 2003; Ward \& Sweller, 1990; Zhu \& Simon, 1987), and using diagrams (Chuy et al., 2011; Duit, 1991; Gan, 2008), have been reported in literature.

Promoting connection. Helping students find meaningful connections is another useful technique that can be used by student facilitators (Baran \& Correia, 2009; Lim, et al., 2011; Ng et al., 2012). Some studies reported several different types of connections that can help facilitate learning, such as linking new knowledge with prior knowledge or personal experience (Caine \& Caine, 1991; Cross, 1999), connecting among different aspects of the lesson (King, 1994), and referring to prior discourse (Abrams, 2003; Moore, 1993).

Summarizing and re-voicing. This is a strategy to distill the most important aspects of class discussion (Hung, et al., 1998). Researchers found that student facilitators can achieve this goal by synthesizing ongoing discussion (Chan et al., 2009; De Smet et al., 2008; Hew \& Cheung, 2008; Lim, et al., 2011; Ng et al., 2012), repeating or paraphrasing important ideas (Chin, 2006; Hmelo-Silver \& Barrows, 2006; Zhang, et al., 2011), and reflecting on the discussion progress (De Smet et al., 2008).

Providing information. Hew and Cheung's study in 2008 revealed that giving information was one of the most frequently used techniques by peer facilitators. To keep the discussion alive and progressing, peer facilitators provided additional information by sharing their prior knowledge or personal experience (Hew \& Cheung, 2008), referring to authoritative sources (De Smet et al., 2008; Ng et al., 2012), presenting alternate/new perspectives (Chan et al., 2009; Hew \& Cheung, 2008; Lim, et al., 2011), pointing out the problems (De Smet et al., 2008; Lim, et al., 2011; Ng et al., 2012), and giving personal opinions (De Smet et al., 2008; Hew \& Cheung, 2008; Lim, et al., 2011; Ng et al., 2012).

Using positive social cues. Positive social cues are the words or symbols that express positive feelings and can help develop positive personal relationships (Chen \& Chiu, 2008). Studies found that peer facilitators used social cues through showing agreement and shared understanding (De Smet et al., 2008; Lim, et al., 2011), giving compliment (De Smet et al., 2008; Lim, et al., 2011), showing appreciation (Hew \& Cheung, 2008; Lim, et al., 2011; Ng, et al., 2010), and inviting contribution (De Smet et al., 2008; Hew \& Cheung, 2008; Lim, et al., 2011; Ng, et al., 2010).

\section{Research Context}

\section{Methods}

This study was conducted in a 15-week graduate-level online course in the School of Education at a northeastern university in the United States. The purpose of this course was to educate students about emerging educational technologies. Weekly online discussion was an important activity in this 
class. Each week, students were provided with readings on a particular technology topic and were required to participate in asynchronous discussions. They took turns playing the role of facilitator. They were required to ask initiating questions and to facilitate the ongoing conversation during the week. The instructor monitored the discussion and provided support when indicated. How the discussion started and evolved primarily depended on the students themselves.

\section{Data Source}

Data were collected from thirteen graduate students who enrolled in this course in Fall 2013. Among them, five were male and nine were female. Five were full-time K-12 teachers, and the others had some tutoring or coaching experience in college. The majority of the students were from educationrelated majors.

A total of 738 discussion posts across seven topics and 21 initiating questions were produced by students in seven, even-numbered weeks (e.g. Week 2, Week 4...Week 14). The number of posts each week ranged from 79 to 143 .

\section{Coding}

The PI model was used to measure cognitive presence. During the coding process, the coding scheme was open to modification and it evolved based on the data. The finalized coding scheme is shown in Table 1.

Table 1.

\begin{tabular}{|c|c|c|}
\hline & $\begin{array}{l}\text { Indicators/ } \\
\text { Learning events }\end{array}$ & Descriptions \\
\hline \multirow[t]{2}{*}{$\begin{array}{l}\text { Triggering } \\
\text { event }(T)\end{array}$} & Describe problems & $\begin{array}{l}\text { Recognize \& describe a problem, and present background information on } \\
\text { the problem }\end{array}$ \\
\hline & Ask questions & Express sense of puzzlement by asking questions \\
\hline \multirow[t]{4}{*}{$\begin{array}{l}\text { Exploration } \\
\text { (E) }\end{array}$} & $\begin{array}{l}\text { Unsubstantiated } \\
\text { disagreement/critique }\end{array}$ & Give unsubstantiated contradiction or critique of previous ideas \\
\hline & Re-voice & Repeat or rephrase the previous ideas, but add no new ideas \\
\hline & $\begin{array}{l}\text { Brainstorm ideas based } \\
\text { on external resources }\end{array}$ & $\begin{array}{l}\text { Exchange information or ideas upon external resource such as: } \\
\text {-Observations or past experience } \\
\text {-Readings, internet, teachers, or other experts } \\
\text { But they are not used as evidence to support a conclusion }\end{array}$ \\
\hline & $\begin{array}{l}\text { Brainstorm ideas based } \\
\text { on personal beliefs or } \\
\text { preferences }\end{array}$ & $\begin{array}{l}\text { Exchange ideas or opinions upon personal beliefs or preferences, such as: } \\
\text {-Add to established points but does not systematically } \\
\text { defend/justify/develop addition } \\
\text {-Present many different ideas/themes in one message } \\
\text {-Offers unsupported opinions }\end{array}$ \\
\hline \multirow[t]{5}{*}{$\begin{array}{l}\text { Integration } \\
\text { (I) }\end{array}$} & $\begin{array}{l}\text { Justify } \\
\text { agreement/addition }\end{array}$ & $\begin{array}{l}\text { Reference to previous message followed by substantiated agreement, e.g., } \\
\text { "I agree...because..."; } \\
\text { Build on, add to others' ideas, and also justify the addition }\end{array}$ \\
\hline & $\begin{array}{l}\text { Justify } \\
\text { disagreement/critique }\end{array}$ & Give justified contradiction/critique of previous ideas \\
\hline & $\begin{array}{l}\text { Justify hypothesis based } \\
\text { on personal beliefs or } \\
\text { preference }\end{array}$ & $\begin{array}{l}\text { Develop and justify a defensible, yet tentative hypothesis based on } \\
\text { personal beliefs or preferences }\end{array}$ \\
\hline & $\begin{array}{l}\text { Justify hypothesis based } \\
\text { on external resources }\end{array}$ & $\begin{array}{l}\text { Develop and justify a defensible, yet tentative hypothesis based on } \\
\text { external resources such as: } \\
\text {-Observations or past experience } \\
\text {-Readings, internet, teachers, or other experts }\end{array}$ \\
\hline & Create solutions & Create and justify a solution to the identified problem \\
\hline $\begin{array}{l}\text { Resolution } \\
\text { (R) }\end{array}$ & Test/ Defend solutions & $\begin{array}{l}\text { Apply the solution in real world, and use the experience to test or defend } \\
\text { the solution }\end{array}$ \\
\hline
\end{tabular}

Note. Modified from Garrison \& Anderson, 2001. 
A single post was selected as the unit of analysis. We read through each post and searched the evidence in the content that corresponded to the description of the codes. Evidence included the overt behaviors or act (e.g., ask a question), connecting words (e.g. because), indicator sentences (e.g., agreement; "I Agree..."), expert resource ("the article pointed out..."), or the researcher's interpretation of the reasoning or argument.

A single unit might involve multiple codes since the cognition and discussion dynamics are complex (Garrison, et al., 2000). Although multiple coding can help reveal the complexity, it also increases the coding inconsistency (Garrison, et al., 2006). Therefore, we selected a coding method that found balance between the two. Particularly, each unit was coded for one category that was the most obvious. When there was more than one obvious category, we selected the highest level of cognitive presence.

Multiple coding was used only when Triggering event co-occurred with other phases of cognitive presence. This is because asking questions, an indicator of a Triggering event, is a very common behavior that can occur throughout the learning process. If we ignored the Triggering event by selecting the highest level of cognitive presence, it would misrepresent the facilitation behavior and limit insights about students' discussion process. Additionally, compared to other types of cognitive presence, a Triggering event characterized by questioning behaviors is relatively easy to identify, and this can decrease the possibility of inconsistency of coding. Therefore, when asking questions co-occurred with other phases of cognitive presence, we allowed multiple coding. For example, this post was coded as Exploration and Triggering event: "I checked out Edmodo, based on Monica's comment, and it seems really useful! I'm curious to hear from those of you who are familiar with it. How do its functions compare to something like Blackboard?" (All names are pseudonyms.)

Table 2 shows the frequency of posts that received 0,1 , and 2 codes.

Table 2.

\begin{tabular}{|c|c|c|}
\hline Number of codes in a post & Frequency & Percentage \\
\hline 0 & 45 & $6.1 \%$ \\
\hline 1 & 643 & $87.1 \%$ \\
\hline 2 & 50 & $6.8 \%$ \\
\hline Total & 738 & $100 \%$ \\
\hline
\end{tabular}

Note. A post with 0 code showed no cognitive presence; it did not mean that there was nothing in the post.

The analysis of peer facilitation techniques was based on both literature review and qualitatively analyzing data through Grounded Theory. We started by reviewing the peer facilitation techniques in literature and identified six types of facilitation that were recommended and supported by empirical studies, including: asking questions, promoting connections, making clarification, summarizing and re-voicing, providing information, and positive social cues. Then we went back to the data and reread the discussion transcripts, with an emphasis on examining the actions and behaviors of peer facilitators. We open-coded the specific behaviors and actions that can help support the particular type of facilitation we identified from literature. For example, in the category of making clarification, we examined the behaviors of peer facilitators in creating clarification (e.g., using analogy, using real-world examples, giving logical explanations).

When coding the peer facilitation techniques, we noticed that some of the specific behaviors in the peer facilitation might fall into multiple categories. For example, "adding details" and "giving examples" fall into both "making clarification" and "providing information"; "inviting contributions" falls into both "asking questions" and "using positive social cues." Although there 
might be some overlap among categories, the context of the action determined which technique was being used. In interpreting the meaning of a single post, we first focused on the local level of the post being coded. If there was any ambiguity in interpretation, the content before or after that post was examined to get a broader context and to maximize the researchers' comprehension (Chi, 1997). When interpretation of peer facilitation techniques was needed for clarification, a "forwardand-backward" approach was used as suggested by Glaser's constant comparative method (1965).

Guided by the constant comparative method, codes were also assigned and created in a "forward-and-backward" way. Particularly, when assigning a unit to a category, this unit was compared with the previous units coded in the same category. When some aspects in the unit could not be explained by the existing $\operatorname{code}(\mathrm{s})$ but were closely associated with the studied construct, the code(s) were refined or new codes were added.

Two outside coders were invited to code the transcripts. The decision about how much content was to be tested was based on the suggestion of using $10 \%-20 \%$ of the total transcripts (Wimmer \& Dominick, 1997). In this study, 105 posts (14\%) were selected at random for the interrater reliability check in analyzing cognitive presence and learning events. Learning events served as the indicators of cognitive presence. All the posts created by peer facilitators were used to check the reliability of the six categories of peer facilitation techniques. Training was provided to outside coders. After the training, the researcher and coders independently coded the selected transcripts. Discrepancies were resolved through discussion. Krippendorff Alpha (Krippendorff, 2012) was used to check the inter-rater reliability. The inter-rater consistency is summarized in Table 3.

Table 3.

The Inter-rater Consistency of Coding Schemes

$\begin{array}{ll}\text { Coding scheme } & \text { Inter-rater consistency } \\ \text { Four phases of cognitive presence } & 0.79 \\ \text { Indicators/Learning events } & 0.70 \\ \text { Six types of peer facilitation } & 0.87 \\ \text { techniques } & \end{array}$

\section{Data Analysis}

Content analysis was conducted to identify cognitive presence. We used quantitative analysis to examine the patterns hidden in the results of the content analysis: the frequency distribution, any reliable difference, or the relationships between and among the studied constructs. Frequency analysis, $\mathrm{t}$ test, and correlation analysis were conducted.

\section{Results and Discussion}

\section{Characteristics of Cognitive Presence}

From all the posts in the data set, four phases of cognitive presence were identified: Triggering event, Exploration, Integration, and Resolution. As shown in Table 4, Exploration $(53.5 \%)$ had the highest proportion of the coded units, followed by Integration (28.9\%), Triggering event (11.2\%), and Resolution (1.1\%). No cognitive presence was found in the remaining 5.5\% of the posts. We conducted t test to compare these percentages and the results confirmed the significant difference between each other at the .000 (thousandths) level. 
Table 4.

Percentage of Different Cognitive Presence Phases

$\begin{array}{ll}\text { Cognitive presence phase } & \text { Percentage } \\ \text { Triggering event } & 11.2 \% \\ \text { Exploration } & 53.5 \% \\ \text { Integration } & 28.9 \% \\ \text { Resolution } & 1.1 \% \\ \text { No cognitive presence } & 5.5 \%\end{array}$

The results revealed that Exploration accounted for the highest percentage of cognitive presence. Such dominance was not unique in the online peer-facilitated situation. Some related studies showed a very similar pattern (Garrison, et al., 2001; Meyer, 2003; Vaughan, et al., 2005). Even in face-to-face class discussion, Exploration still had the obviously highest proportion (Vaughan, et al., 2005).

One possible explanation is that it is natural for students to spend the most time on Exploration in their inquiry activities. This is because Exploration is of a divergent nature and requires time to explore different pieces of information thoroughly (Stein, et al., 2007). Also, Exploration is more likely to be interesting since exposure to different new ideas filled the experience with newness and wonder (Garrison \& Anderson, 2003). Garrison et al. (2001) assume that Integration and Resolution are more intellectually demanding, and students tend to stay in their comfort zone by not leaving the Exploration phase.

We also examined the learning events that served as the evidence of cognitive presence. The distribution of the learning events is shown in Figure 2. Correlation analyses were conducted to reveal the relationship between different learning events. The unit of correlation analysis was a single discussion thread. We analyzed the correlation of the frequencies of learning events occurred in the 21 discussion threads.

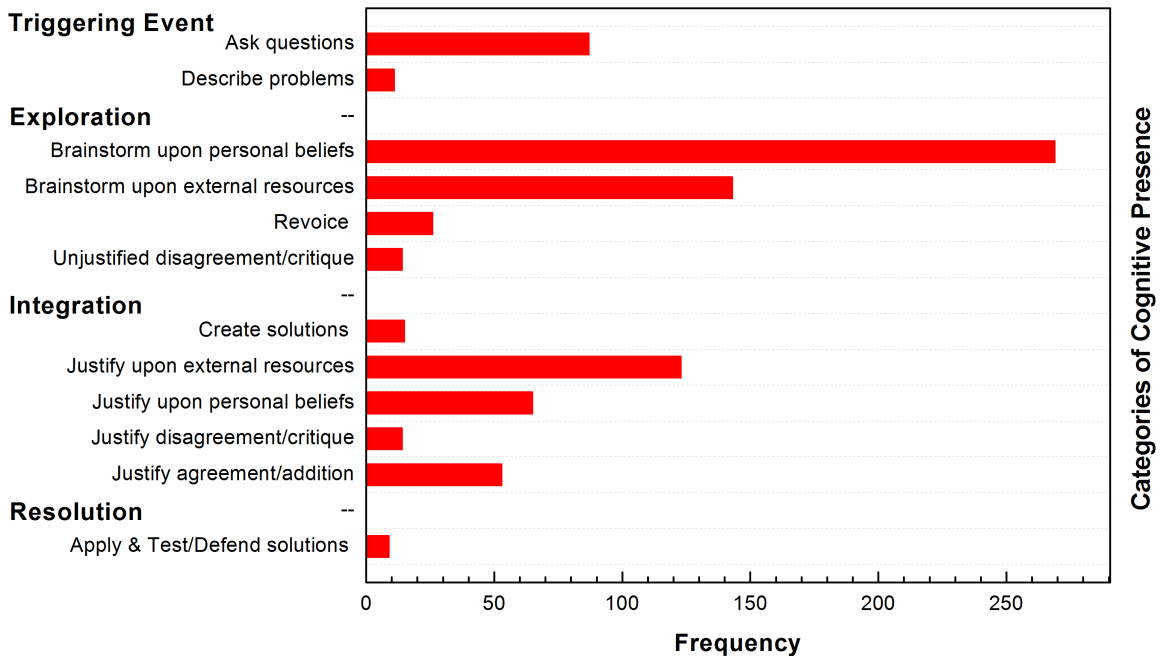

Figure 2. Number of learning events in online discussion

We obtained some findings about the learning events in each phase of cognitive presence. First, students asked questions significantly more than they described problems $(\mathrm{t}=-9.06, \mathrm{p}<.001)$. Also, as shown in Table 5, we noticed that problem describing was significantly correlated with brainstorming based upon personal beliefs (Pearson $\mathrm{r}=.14, \mathrm{p}<.001$ ) and justifying hypothesis (Pearson $\mathrm{r}=.218-.349, \mathrm{p}<.01$ ). The process of describing a problem involves locating, 
understanding and articulating a problem. We tend to believe that describing a problem demands more cognitive involvement than simply asking a question. Asking questions could be a natural reaction when students encountered problems. Thus, in class discussion, when students asked a question, a peer facilitator could encourage students to articulate more about the problem they identified. Second, in the Exploration phase, students brainstormed ideas significantly more based on personal beliefs and opinions rather than on empirical resources $(t=-6.90, p<.001)$. In Integration, the opposite was observed. Students justified their hypothesis more based upon empirical evidence than on their personal beliefs $(\mathrm{t}=-4.43, \mathrm{p}<.001)$. Third, solution creation was significantly correlated with justifying agreement (Pearson $\mathrm{r}=0.201, \mathrm{p}<.01$ ) and marginally correlated with justifying hypothesis on empirical evidence (Pearson $r=0.07, p=.063$ ). It seemed that in discussion inquiries, students were more likely to produce solutions when they actively involved in developing integrated thinking and making logical arguments.

Table 5.

\section{The Correlations of Indicators/Learning Events}

\begin{tabular}{|c|c|c|c|c|c|c|c|c|c|c|c|c|}
\hline $\begin{array}{l}\text { Indicators/ } \\
\text { Learning events }\end{array}$ & DP & AQ & UD & $\mathbf{R V}$ & $\mathbf{B E}$ & BP & JA & JD & JHP & JHE & CS & AT \\
\hline $\begin{array}{l}\text { Describe problems } \\
\text { (DP) }\end{array}$ & 1 & 0.247 & 0.030 & 0.302 & 0.013 & $0.140^{* *}$ & 0.024 & 0.373 & $0.218^{*}$ & $0.349^{*}$ & 0.247 & 0.211 \\
\hline Ask questions (AQ) & & 1 & 0.251 & 0.271 & 0.136 & 0.196 & 0.273 & 0.146 & 0.003 & 0.102 & 0.282 & 0.123 \\
\hline $\begin{array}{l}\text { Unsubstantiated } \\
\text { disagreement/ } \\
\text { critique (UD) }\end{array}$ & & & 1 & 0.073 & $.439^{*}$ & 0.177 & 0.118 & 0.076 & 0.247 & 0.069 & 0.156 & 0.081 \\
\hline Re-voice (RV) & & & & 1 & 0.266 & 0.424 & -0.415 & -0.329 & -0.065 & -0.224 & 0.116 & 0.287 \\
\hline $\begin{array}{l}\text { Brainstorm ideas based } \\
\text { on external resources } \\
\text { (BE) }\end{array}$ & & & & & 1 & $.525^{*}$ & 0.354 & 0.006 & $.459^{*}$ & 0.328 & 0.043 & $.559^{* *}$ \\
\hline $\begin{array}{l}\text { Brainstorm ideas based } \\
\text { on personal beliefs or } \\
\text { preferences (BP) }\end{array}$ & & & & & & 1 & 0.193 & 0.222 & 0.371 & 0.239 & 0.141 & 0.386 \\
\hline $\begin{array}{l}\text { Justify agreement/ } \\
\text { addition (JA) }\end{array}$ & & & & & & & 1 & -0.204 & 0.327 & $.624^{* *}$ & $0.201^{*}$ & 0.218 \\
\hline $\begin{array}{l}\text { Justify disagreement/ } \\
\text { critique (JD) }\end{array}$ & & & & & & & & 1 & 0.090 & 0.307 & 0.294 & 0.153 \\
\hline $\begin{array}{l}\text { Justify hypothesis } \\
\text { based on personal } \\
\text { beliefs or preference } \\
\text { (JHP) }\end{array}$ & & & & & & & & & 1 & 0.116 & 0.088 & 0.082 \\
\hline $\begin{array}{l}\text { Justify hypothesis } \\
\text { based on external } \\
\text { resources (JHE) }\end{array}$ & & & & & & & & & & 1 & 0.070 & 0.340 \\
\hline Create solutions (CS) & & & & & & & & & & & 1 & 0.030 \\
\hline Apply, test, defend & & & & & & & & & & & & 1 \\
\hline
\end{tabular}

(AT)

Note. ${ }^{*} \mathrm{p}<.05, * * \mathrm{p}<.01, * * * \mathrm{p}<.001$

Although very few, if any, empirical studies have confirmed the hierarchical relationship among the four phases of cognitive presence, researchers tend to consider Integration and Resolution as the higher level of cognitive presence (e.g. Kalelioglu \& Gülbahar, 2014; Kozan, 2016; Shea \& Bidjerano, 2009; Stein et al., 2013). We followed this assumption, and in Figure 3 we demonstrated the distribution of higher- and lower-level cognitive presence. Although students exhibited cognitive presence in $95 \%$ of the posts, their cognitive presence primarily aggregated at the lower level. Akyol and Garrison (2011) pointed out that this pattern can be changed by 
instructional design and facilitation. Their study proved that when facilitative intervention was added, Integration was improved greatly and achieved the highest percentage among the four phases. Thus, in the next step, we studied how the peer facilitation affected students' cognitive presence and what peer facilitation techniques were used.

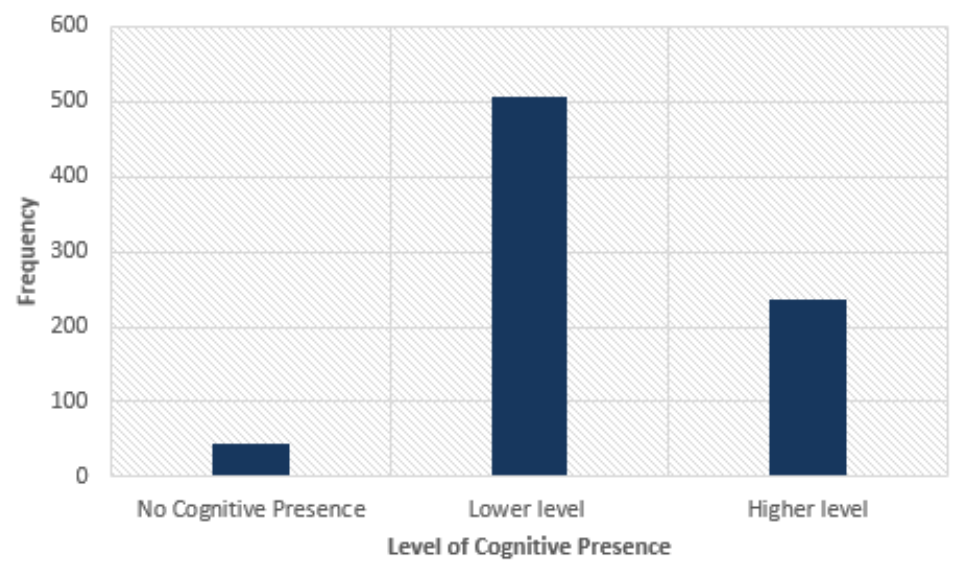

Figure 3. The frequency of different cognitive presence levels

\section{How Types of Initiating Questions Asked by Peer Facilitators Affect the Level of Cognitive Presence}

An important job for the peer facilitators is to ask initiating questions to start the discussion. In the present study, we examined the effects of the type of initiating questions on the level of cognitive presence.

Hakkarainen (2002) identified two types of questions that occur in students' inquiry: (a) factual questions which ask for factual recall of definition of terms, or description of processes/objects, and (b) explanatory questions which seek conceptual understanding through explanation, inference, and speculation. We coded the initiating questions from 21 discussion threads and divided them into two groups. The group of factual questions included questions that addressed facts about certain kinds of technology, definitions of a technological term, or experience of technology use (e.g., Have you ever used other technology of Web 2.0, except for Wiki and Blogs? Make a brief description of it.). The group of explanatory questions included the ones inviting explanation about a technology-choosing decision, or justification on opinions of a debated issue (e.g., Haefner argues that online courses should utilize both synchronous and asynchronous communication. Do you agree that both forms of communication are necessary for a successful online course? Why or why not?). Initiating questions that included both factual and explanatory sub-questions or that crossed both categories were coded then as explanatory. Working independently, two coders coded the 21 initiating questions. Their coding results were then compared and a full agreement was reached.

We expected that factual questions would induce more lower-level cognitive presence, whereas explanatory questions would induce a higher-level cognitive presence. However, in peerfacilitated environments, students' responses might be more unpredictable as they might feel comfortable in frankly expressing their thought and feelings (Hew, 2015). It is possible that any type of responses could emerge, and then any level of cognitive presence might be provoked. Does the effect of question type exist in peer-facilitated discussion? To answer this question, we compared the students' cognitive presence between the two question groups. As shown in Table 
6 , lower-level cognitive presence was observed in the factual group $(\mathrm{t}=-2.73, \mathrm{p}<.05)$, and more higher-level cognitive presence occurred in the explanatory group $(\mathrm{t}=4.86, \mathrm{p}<.001)$.

Table 6.

Comparison of Cognitive Presence (CP) in Two Types of Questions

\section{Factual Questions}

$\begin{array}{ll} & \begin{array}{l}\text { \# of posts with low- } \\ \text { level CP per thread }\end{array} \\ \text { Mean } & 32.2 \\ \text { SD } & 9.09\end{array}$

\# of posts with high-
level CP per thread
7.0
1.67

\# of posts with high-

1.67

\section{Explanatory Questions}

\# of posts with low- $\quad$ \# of posts with high-

level CP per thread level CP per thread

20.9

$6.85 \quad 3.91$

Did the pattern revealed in Table 6 result from the different types of initiating questions, or from the different involvement of peer facilitators during discussion? To answer this question, we compared the cognitive presence of peer facilitators between the discussion threads started by factual questions and the threads started by explanatory questions. Figure 4 demonstrated the differences in facilitators' involvement, any of which did not reach the .05 significance level. We tend to believe that, except the type of initiating questions, the involvement of peer facilitators was equivalent for the two groups.

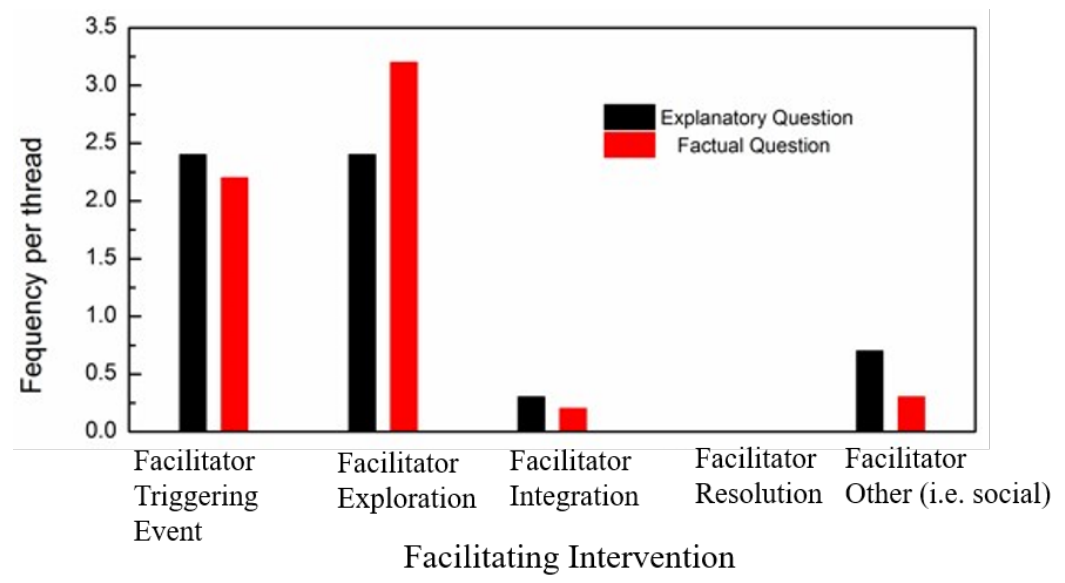

Figure 4. Comparison of the involvements (cognitive presence) of peer facilitators

We also compared the learning events of all the student participants. As illustrated in Table 7 , discussion threads begun by factual initiating questions contained more brainstorming upon external resources $(\mathrm{t}=-2.78, \mathrm{p}<.05)$, and marginally more brainstorming upon personal beliefs $(\mathrm{t}=-$ $1.98, \mathrm{p}=.062)$ and marginally more re-voicing $(\mathrm{t}=-1.83, \mathrm{p}=.083)$. In contrast, in discussions begun by explanatory questions, we observed more justifying agreement and building on others' ideas $(\mathrm{t}=4.34, \mathrm{p}<.001)$, more justifying hypothesis based on empirical evidence $(\mathrm{t}=3.13, \mathrm{p}<.05)$, and marginally more applying/testing solution ideas $(\mathrm{t}=-1.84, \mathrm{p}=.082)$. 
Table 7.

Comparison of Learning Events in Two Types of Questions

\begin{tabular}{|c|c|c|c|c|}
\hline \multirow[t]{2}{*}{ Question type } & \multicolumn{2}{|c|}{ Factual question } & \multicolumn{2}{|c|}{ Explanatory question } \\
\hline & Mean & SD & Mean & SD \\
\hline Describe problems & 0.33 & 0.52 & 0.60 & 0.63 \\
\hline Ask questions & 4.33 & 2.94 & 4.07 & 2.89 \\
\hline $\begin{array}{l}\text { Unsubstantiated } \\
\text { disagreement/critique }\end{array}$ & 0.17 & 0.41 & 0.87 & 0.99 \\
\hline Re-voice & 1.83 & 0.98 & 1.00 & 0.93 \\
\hline $\begin{array}{l}\text { Brainstorm ideas based on } \\
\text { external resources }\end{array}$ & 12.17 & 6.15 & 4.67 & 3.87 \\
\hline $\begin{array}{l}\text { Brainstorm ideas based on } \\
\text { personal beliefs or preferences }\end{array}$ & 15.83 & 6.21 & 11.60 & 3.58 \\
\hline Justify agreement/addition & 0.33 & 0.52 & 3.40 & 2.61 \\
\hline Justify disagreement/critique & 0.50 & 0.84 & 0.73 & 1.03 \\
\hline $\begin{array}{l}\text { Justify hypothesis based on } \\
\text { personal beliefs or preference }\end{array}$ & 2.33 & 1.03 & 3.40 & 2.13 \\
\hline $\begin{array}{l}\text { Justify hypothesis based on } \\
\text { external resources }\end{array}$ & 3.33 & 1.97 & 6.87 & 3.07 \\
\hline Create solutions & 0.33 & 0.52 & 0.87 & 1.19 \\
\hline Apply, test, defend & 0.83 & 0.75 & 0.27 & 0.59 \\
\hline
\end{tabular}

Therefore, the types of initiating questions asked by peer facilitators significantly influenced students' cognitive presence. When students were asked factual questions, they were more likely to engage in Exploration through fact recalling and restating, which could be considered as a lower level of learning. However, when students were asked explanatory questions, they were more likely to engage in Integration events. A higher level of learning occurred through connecting, justifying, and applying ideas.

\section{Peer Facilitation Techniques for Enhancing Cognitive Presence}

Based on literature review, we identified six types of peer facilitation: questioning, making clarification, promoting connection, summarizing and re-voicing, providing information, and using positive social cues. Using the grounded theory approach, we further analyzed all the facilitation behaviors of peer facilitators that support these six types of facilitation. These strategies, and the specific techniques that exemplify each, are summarized in Table 8 . In Table 8, we also cited the studies from the literature that can provide evidence in support of the effectiveness of the facilitation techniques. 
What if Online Students Take on the Responsibility: Students' Cognitive Presence and Peer Facilitation Techniques

Table 8.

Summary of Peer Facilitation Techniques

Strategy Specific techniques (supportive literature) and examples

Questioning Ask explanatory questions (Graesser, et al., 2002; Hakkarainen, 2002; Hmelo-Silver \& Barrows, 2008; King, 1999)

Example: Would you like to explain more about reasons behind this relationship?

Ask factual questions (King, 2007)

Example: I am not familiar with some of the tools you mentioned above. Are they free?

Check joint understanding (Hmelo-Silver \& Barrows, 2008)

Example: You mean subscribing digitally, correct? Vs. a magazine/newspaper/journal subscription that comes in the mail

Make Give explanations through logical reasoning (but do not use analogy or real-world examples)

clarification (King, 2007; Gao, 2013; Roscoe \& Chi, 2007)

Example of telling "why" and "how": One reason that you have a blog group is that you will have an "audience"--your group members, in addition to the instructors, to read your /posts and share thoughts with you...

Example of elaborating on a topic: I am finding that I like Edmodo because it's safe and colorful, but it's very much like Facebook and students try to treat it as such so it's a conversation we have had over time about conversations there and what the purpose of Edmodo for us is! I am glad you noticed they have a demo as well.

Give real-world examples (Atkinson, et al., 2003; Roscoe \& Chi, 2008; Zhu \& Simon, 1987)

Example: In my understanding no-tech AT usually involves no real material assistance. The example given in Dr. Lei's introduction is physical therapy.

Create analogies (Capon \& Kuhn, 2010; Duit, et al., 2001; Roscoe \& Chi, 2008)

Example: If we describe [consider] the web as a house, the Web 1.0 is the foundation of the house, and Web 2.0 is the house upper [on] the ground

Promote Cue students' prior knowledge or personal experience (King, 1994; O'keefe \& Nadel, 1978;

connection Pressley et al., 1992)

Example: Please contribute your thought about the above quote. Draw from your experiences as a student or teacher.

Cue reading materials (King, 1994)

Example: In Downes' article on educational blogging, Will Richardson is quoted as saying: "By its very nature, assigned blogging in schools cannot be blogging. It's contrived. No matter how much we want to spout off about the wonders of audience and readership, students who are asked to blog are blogging for an audience of one, the teacher" (p. 24). Do you agree with Richardson? Why or why not?

Cue class projects (King, 1994)

Example: I couldn't help from thinking about the blog assignment in this very class--does it meet the requirements that you mentioned?

Cue previous discussion messages (Abrams, 2003; Moore, 1993)

Example: Bringing cybersecurity knowledge back home is so important. I have also been thinking about the teachers themselves. As we have discussed in past weeks some teachers are against or hesitant towards technology, but what if they have to use it?

Summarize Synthesize available ideas (Hew et al., 2010; Hmelo-Silver \& Barrows, 2006; Lim \& Cheah, 2003)

\& revoice Example: In the last few days here in class we have heard (or read) many thoughts about the responsibilities educators must take into consideration with their "internet presence." Your question was about whether or not an opinion leader should hold a neutral or mild position on sensitive or controversial topics?

Revoicing-highlight the important idea(s) (Hmelo-Silver \& Barrows, 2006; Koschmann, et al., 1999; Zhang, et al., 2011)

Example of repeating students' words: I also like that you mention "Education needs to be ongoing and current."

Example of paraphrasing students' ideas: You raised a very sensitive point that students may become disinterested which is true and a problem as well.

Reflect on the discussion progress (Hmelo-Silver \& Barrows, 2006)

Example: Based on numerous posts on the topic of teachers and the standards for personal behavior, we are mostly in agreement that we all need to be more aware of what we're posting online... 
What if Online Students Take on the Responsibility: Students' Cognitive Presence and Peer Facilitation Techniques

Table 8. (continued)

Summary of Peer Facilitation Techniques

Strategy Specific techniques (supportive literature) and examples

Provide Share personal experience (Hew \& Cheung, 2008; Kobbe, et al., 2007)

information Example: Students who know they have difficulties in learning but don't want to admit to it; and that there are still teachers and school who do not have a background in teaching students with disabilities. I had one friend growing up that knew he had trouble learning, but never said anything to his parents or teachers. This backfired on him as he began to fall behind academically and before he knew it he was doing poorly in school before he did anything about it. I grew up in this technological advancement age and for the most part, some of these assistive technology tools were beginning to be available for students; which would have greatly helped him in his studies.

Provide information from authoritative sources (Hew \& Cheung, 2008; Kennedy \& Kennedy, 2010; Kobbe, et al., 2007)

Example: I would like to share this quote by John Dewey, "If we teach today's students as we taught yesterdays, we rob them of tomorrow." We want to be proactive in our thinking with the end in mind. To do so we have to take into consideration the skills and strategies the younger generation will need in order to be successful.

Present alternate perspectives (Hew \& Cheung, 2011)

Example: Don't you think it would be better to merge schools together and let them use well-equipped technology and tools together?

Identify problems (Hew \& Cheung, 2011)

Example: ...Safety of the information would be a big problem. Many hackers could steal your

information and then steal your money.

Give personal opinions (Hew \& Cheung, 2011)

Example: I do think there are some strategies you develop over time that will help you with any online class.

Use Show agreement/empathy/shared understanding (Schwarz et al., 2007)

positive $\quad$ Example: I agree we need to teach the process of how this might look...

social clues You've got a point there! I know what it feels like to teach in a place where technology is not available.

It makes me so upset when I hear stories like the one XX posted, and it seems like stories like these are just increasing...

Praise (Chen \& Chiu, 2008)

Example: I like how you split up the opportunities and challenges in your post to clearly define both parts of the discussion questions.

Show thanks (Hew \& Cheung, 2011)

Example: Thank you for bringing up critical point here. People's attitude towards using technology really matters and should be taken into account.

Invite students to contribute (Hew \& Cheung, 2008; Hew \& Cheung, 2011)

Example: I asked a few questions in relation to $X X^{\prime}$ 's post, but open all of my questions up to the entire group, so feel free to answer other questions as they come up, and please ask any questions of the group as well.

Among the six types of facilitation techniques, providing information and questioning were the most frequently used techniques. In this study, peer facilitators provided information through sharing personal stories (39.4\% of all the occurrences of providing information), introducing relevant resources $(15.2 \%)$, giving personal opinions $(53.0 \%)$, posing alternative perspectives $(6.1 \%)$, and identifying problems (12.1\%). Giving information is a "fundamental move" of a facilitator that may elicit new directions of thinking and bring important resources into group awareness (Kennedy, 2004). According to Schellens et al. (2005), a certain number of posts are needed for a discussion before moving to a higher level of knowledge construction. Hew and Cheung (2011) found that the strategy of providing information served this purpose. 
Questioning was another commonly used strategy. We found that peer facilitators asked more explanatory questions in opening a discussion or following up a student's response. A total of $81.8 \%$ of the questions they asked fell into this category. Peer facilitators asked explanatory questions to elicit logical reasoning and explaining. Compared to explanatory questions, factual questions that lead to the telling of factual information were asked much less frequently (16.4\%).

Peer facilitators created positive social cues through showing agreement/empathy/shared understanding (59.6\% of all the occurrences of using positive social cues), expressing their compliment (25.5\%) appreciation (36.2\%), and inviting contribution from students (4.3\%). Social cues are the words or symbols that reflect personal feelings and emotions (Chen \& Chiu, 2008). Positive social cues can help create an environment where students feel that their contributions are expected and valued by peers (Chen \& Chiu, 2008), and can also help minimize students' fear of having their ideas open to peer review (Hew \& Cheung, 2011). However, this technique needs to be used carefully. Too many social cues might distract students' attention from in-depth thinking to surface social interaction (Hara, et al., 2000; Walther, 1996). The social cues of showing appreciation and praise became less effective when facilitators used them for almost every student without pointing out why and how their posts contributed to the group (Hew \& Cheung, 2011).

Other peer facilitation techniques were employed. Peer facilitators applied the technique of summarizing and re-voicing to emphasize the important aspects of the class discussion. Among all the occurrences of this technique, $72.7 \%$ were restating students' ideas through repeating or paraphrasing. They also used the technique of making clarification, and $92 \%$ of clarifications were made through explaining "why" and "how" and elaborating to provide more details. To make a clarification more effective, they also used examples $(28.9 \%)$ and analogies $(2.6 \%)$ to make explicit the key features and relationships of/among concepts. In addition, peer facilitators used the technique of promoting connections. For example, they connected new knowledge with students' prior knowledge or personal experiences $(51.7 \%$ of all the occurrences of promoting connections). In this way, they helped students develop new understanding based on the things familiar to students. They also asked students to connect the class discussion with other class activities in the course, such as article reading (41.4\%), course projects $(3.4 \%)$, or previous class discussions $(20.7 \%)$.

We also found that peer facilitators tended to use multiple facilitation techniques in a single post. As shown in Table 8, for peer facilitators, the total number of the occurrences of all the facilitation techniques was much greater than the total number of posts they contributed. This phenomenon was also reported in Chan et al.'s study in 2009, and they revealed that the combination use of different peer facilitation techniques is more likely to increase the discussion continuity.

Table 9 shows the frequency of facilitation techniques used by peer facilitators. 
Table 9.

Frequency of Peer Facilitation Techniques

\begin{tabular}{|c|c|c|c|c|c|c|c|c|}
\hline \multirow{2}{*}{$\begin{array}{l}\text { Peer- } \\
\text { facilitator }\end{array}$} & \multicolumn{6}{|c|}{ Peer facilitation technique } & \multirow{2}{*}{$\begin{array}{l}\text { \# of } \\
\text { occurrence }\end{array}$} & \multirow{2}{*}{$\begin{array}{l}\text { \# of } \\
\text { posts }\end{array}$} \\
\hline & Questioning & $\begin{array}{l}\text { Make } \\
\text { clarification }\end{array}$ & $\begin{array}{l}\text { Promote } \\
\text { connection }\end{array}$ & $\begin{array}{l}\text { Summarize } \\
\& \text { re-voice }\end{array}$ & $\begin{array}{l}\text { Provide } \\
\text { information }\end{array}$ & $\begin{array}{l}\text { positive } \\
\text { social cues }\end{array}$ & & \\
\hline$\overline{\mathrm{A}}$ & 9 & 5 & 4 & 3 & 6 & 4 & 31 & 14 \\
\hline B & 9 & 11 & 7 & 13 & 20 & 11 & 71 & 28 \\
\hline $\mathrm{C}$ & 16 & 12 & 8 & 17 & 18 & 19 & 90 & 34 \\
\hline $\mathrm{D}$ & 3 & 2 & 3 & 4 & 5 & 4 & 21 & 9 \\
\hline $\mathrm{E}$ & 4 & 1 & 2 & 1 & 4 & 1 & 13 & 6 \\
\hline $\mathrm{F}$ & 10 & 4 & 3 & 8 & 6 & 5 & 36 & 16 \\
\hline $\mathrm{G}$ & 4 & 3 & 2 & 1 & 5 & 2 & 17 & 8 \\
\hline Total & 55 & 38 & 29 & 47 & 64 & 46 & 279 & 115 \\
\hline
\end{tabular}

To examine the relationship between these peer facilitation techniques and students' cognitive presence, we conducted correlation analysis. As illustrated in Table 10, all the peer facilitation techniques were found to be significantly associated with Triggering event. Summarizing and re-voicing, providing information, and using positive social cues were significantly related with Exploration level of cognitive presence. Although the literature typically shows that these facilitation techniques do affect students' higher-level thinking and learning, we did not, in this study, find significant correlations between these facilitation techniques and cognitive presence of Integration and Resolution.

Table 10.

The Correlation Between Peer Facilitation Techniques and Students' Cognitive Presence

\begin{tabular}{|c|c|c|c|c|c|c|c|c|}
\hline \multirow[t]{2}{*}{ Peer facilitation strategy } & \multicolumn{2}{|c|}{ Triggering event } & \multicolumn{2}{|c|}{ Exploration } & \multicolumn{2}{|c|}{ Integration } & \multicolumn{2}{|c|}{ Resolution } \\
\hline & $\mathrm{R}$ & $\mathrm{p}$ & $\mathrm{r}$ & $\mathrm{P}$ & $\mathrm{R}$ & $\mathrm{p}$ & $\mathrm{r}$ & $\mathrm{p}$ \\
\hline Questioning & $.804^{* *}$ & .000 & .299 & .187 & .066 & .776 & .132 & .569 \\
\hline Make clarification & $.606^{* *}$ & .004 & .337 & .135 & .282 & .215 & .247 & .281 \\
\hline Promote connection & $.794^{* *}$ & .000 & .362 & .107 & .068 & .770 & .100 & .666 \\
\hline Summarize \& re-voice & $.494^{*}$ & .034 & $.453^{*}$ & .039 & .329 & .145 & .023 & .923 \\
\hline Provide information & $.825^{* *}$ & .000 & $.581^{* *}$ & .006 & .121 & .602 & .012 & .690 \\
\hline Use positive social cues & $.778^{* *}$ & .000 & $.557^{* *}$ & .009 & .193 & .403 & .020 & .931 \\
\hline
\end{tabular}

\section{Conclusions}

In this study, we let students take on the responsibility of facilitating their class discussions. In the peer-facilitated environment, we examined the cognitive presence of students and the facilitation techniques used by peer facilitators.

Our analyses revealed several major findings. First, in a peer-facilitated online environment, students demonstrated four types of cognitive presence: Triggering event, Exploration, Integration, and Resolution. However, students' cognitive presence mostly stayed at a relatively lower level. Then, the pressing issue was to determine the facilitation practices that can promote students' cognitive presence development. 
Second, peer facilitators' initiating questions affected students' level of cognitive presence. The results of this study have revealed the statistically significant association between peer facilitators' involvement and students' higher-level cognitive presence. Even though the dynamics in the class discussion is complicated, the initiating questions still have the power to influence the subsequent dialogic inquiry. We found that factual questions (such as what, who, when) are more likely to induce retelling and descriptive articulating, whereas explanatory questions (such as why, how, what-if) have more potential to trigger a higher level of integrated thinking such as idea connection, justification, and application. It is reasonable to assume that this also applies to the follow-up questions in discussion.

Third, we investigated the facilitation techniques that were used by peer facilitators. The techniques included: questioning, making clarification, promoting connections, summarizing and re-voicing, providing information, and using positive social cues. We found that peer facilitators tend to use a combination of facilitation techniques in a post when responding to the students. The results also revealed the association between these peer facilitation techniques and students' cognitive presence of Triggering event and Exploration. It's possible that some facilitation techniques are more supportive of different levels of cognitive presence. This is suggested by the fact that three facilitation techniques - summarizing and re-voicing, providing information, and using positive social cues-were significantly correlated with Exploration, while the other three techniques were not. Evidence from literature supported the association between these techniques and higher-level thinking. However, we did not find the significant correlation between the peer facilitation techniques and higher-level cognitive presence. One possible reason is the small sample size ( 21 threads by 13 students). If sample size increases, we tend to believe that more information will be obtained about the association between peer facilitation and higher-level cognitive presence. Another possible reason could be the sizable restriction of range of higher levels of cognitive presence. Especially for Resolution, the percentage is very low. The lack of significant correlations may be a result of extremely low occurrence of higher-level cognitive presence for those discussions. A third reason could be that peer facilitation behaviors were not used intensively enough to allow us to detect the statistical association. In this study, these students were not trained in using facilitation techniques, and we examined their naturally-emerged facilitation behaviors. These facilitation techniques might not have been used frequently enough, and they may not have been used at the proper point. As a result of this, it is possible that we were not able to detect the correlation as expected. Literature also suggested that students might not spontaneously function effectively to facilitate a convesation (Weinberger, et al., 2005). They may fail to listen to peers' voices, ignore the important aspects of the discussion, or miss the opportunities that can move the discussion to a higher level. All this will consequently influence the quality of discussion. Thus, we recommend providing student facilitators with suppport or training on using these techniques to enhance their awareness/use of the faciliation techniques.

Future research includes experimenting with these peer facilitation techniques where we train student facilitators on using these techniques. We would like to conduct conversation analysis and time series analysis on discussion threads/episodes that have involved active cognitive presence and peer facilitation. In this way, we can examine the dynamic process of how cognitive presence evolves overtime, how peer facilitators use facilitation techniques, and how these techniques affect students' cognitive presence development. To address the sample size/range restriction issue, future studies would collect more data from a larger sample of discussions with more examples of higher-level cognitive presence. 


\section{References}

Abrams, Z. I. (2003). The effect of synchronous and asynchronous CMC on oral performance in German. The Modern Language Journal, 87(2), 157-167.

Akyol, Z., \& Garrison, D. R. (2011). Understanding Cognitive Presence in an Online and Blended Community of Inquiry: Assessing Outcomes and Processes for Deep Approaches to Learning. British Journal of Educational Technology, 42(2), 233-250.

Anderson, R. (1976). Peer facilitation: History and issues. Elementary School Guidance \& Counseling, 11(1), 16-25.

Asoodar, M., Atai, M. R., Vaezi, S., \& Marandi, S. S. (2014). Examining effectiveness of communities of practice in online English for academic purposes (EAP) assessment in virtual classes. Computers \& Education, 70, 291-300.

Atkinson, R. K., Renkl, A., \& Merrill, M. M. (2003). Transitioning from studying examples to solving problems: Effects of self-explanation prompts and fading worked-out steps. Journal of Educational Psychology, 95(4), 774.

Baran, E., \& Correia, A. P. (2009). Student - led facilitation strategies in online discussions Distance Education, 30(3), 339-361.

Beach, P., \& Willows, D. (2017). Understanding Teachers' Cognitive Processes during Online Professional Learning: A Methodological Comparison. Online Learning, 21(1), 60-84.

Capon, N., \& Kuhn, D. (2004). What's so good about problem-based learning? Cognition and Instruction, 22(1), 61-79.

Celentin, P. (2007). Online education: Analysis of interaction and knowledge building patterns among foreign language teachers. International Journal of E-Learning \& Distance Education, 21(3), 39-58.

Caine, R. and Caine, G. (1999). Making Connections: Teaching and the Human Brain. Somerset, NJ: Addison Wesley. Retrieved from: http://files.eric.ed.gov/fulltext/ED335141.pdf

Carlsen, W. S. (1993). Teacher knowledge and discourse control: Quantitative evidence from novice teachers' classrooms. Journal of Research in Science Teaching, 30, 471-481.

Chan, J. C. C., Hew, K. F., \& Cheung, W. S. (2009). Asynchronous online discussion thread development: examining growth patterns and peer-facilitation techniques. Journal of Computer Assisted Learning, 25(5), 438-452.

Chen, G., \& Chiu, M. M. (2008). Online discussion processes: Effects of earlier messages' evaluations, knowledge content, social cues and personal information on later messages. Computers \& Education, 50(3), 678-692.

Chi, M. T. (1997). Quantifying qualitative analyses of verbal data: A practical guide. The Journal of the Learning Sciences, 6(3), 271-315.

Chi, M. T., Siler, S. A., Jeong, H., Yamauchi, T., \& Hausmann, R. G. (2001). Learning from human tutoring. Cognitive Science, 25(4), 471-533.

Chin, C. (2006). Classroom interaction in science: Teacher questioning and feedback to students' responses. International Journal of Science Education, 28(11), 1315-1346.

Choi, I., Land, S. M., \& Turgeon, A. J. (2005). Scaffolding peer-questioning strategies to facilitate metacognition during online small group discussion. Instructional Science, 33(5-6), 483-511. 
Chuy, M., Zhang, J., Resendes, M., Scardamalia, M., \& Bereiter, C. (2011). Does contributing to a knowledge building dialogue lead to individual advancement of knowledge. In Connecting computer-supported collaborative learning to policy and practice: CSCL2011 conference proceedings (Vol. 1, pp. 57-63).

Cross, K. P. (1999). Learning is about making connections: the cross papers number 3. Mission Viejo, CA: League for Innovation in the Community College and Educational Testing Service. Retrieved from: http://files.eric.ed.gov/fulltext/ED432314.pdf

Darabi, A., Arrastia, M. C., Nelson, D. W., Cornille, T., \& Liang, X. (2011). Cognitive presence in asynchronous online learning: A comparison of four discussion strategies. Journal of Computer Assisted Learning, 27(3), 216-227.

de Leng, B. A., Dolmans, D. H., Jöbsis, R., Muijtjens, A. M., \& van der Vleuten, C. P. (2009). Exploration of an e-learning model to foster critical thinking on basic science concepts during work placements. Computers \& Education, 53(1), 1-13.

de Smet, M., Van Keer, H., \& Valcke, M. (2008). Blending asynchronous discussion groups and peer tutoring in higher education: An exploratory study of online peer tutoring behaviour. Computers \& Education, 50(1), 207-223.

Duit, R., Roth, W. M., Komorek, M., \& Wilbers, J. (2001). Fostering conceptual change by analogies-between Scylla and Charybdis. Learning and Instruction, 11(4), 283-303.

Fauske, J., \& Wade, S. E. (2003). Research to practice online: Conditions that foster democracy, community, and critical thinking in computer-mediated discussions. Journal of Research on Technology in Education, 36(2), 137-153.

Gan, Y. (2008). Drawing out Ideas: Student-Generated Drawings' Roles in Supporting Understanding of "light". Paper presented at the Institute for Knowledge Innovation and Technology: Summer Institute, Toronto, ON. Retrieved from: http://ikit.org/SummerInstitute2007/Highlights/SI2007_papers/32_Gan.pdf

Gao, F., Zhang, T., \& Franklin, T. (2013). Designing asynchronous online discussion environments: Recent progress and possible future directions. British Journal of Educational Technology, 44 (3), 469-483.

Garrison, D. R. (2003). Cognitive presence for effective asynchronous online learning: The role of reflective inquiry, self-direction and metacognition. Elements of quality online education: Practice and direction, 4, 47-58.

Garrison, D. R., Cleveland-Innes, M., Koole, M., \& Kappelman, J. (2006). Revisiting methodological issues in transcript analysis: Negotiated coding and reliability. The Internet and Higher Education, 9(1), 1-8.

Garrison, D. R., \& Akyol, Z. (2013). Toward the development of a metacognition construct for communities of inquiry. The Internet and Higher Education, 17, 84-89.

Garrison, D. R., \& Akyol, Z. (2015). Toward the development of a metacognition construct for communities of inquiry. The Internet and Higher Education, 24, 66-71.

Garrison, D. R. \& Anderson, T. (2003). E-Learning in the 21st century: a framework for research and practice. London: Routledge/Falmer.

Garrison, D. R., Anderson, T., \& Archer, W. (2001). Critical thinking, cognitive presence, and computer conferencing in distance education. American Journal of Distance Education, $15(1), 7-23$. 
Gašević, D., Adesope, O., Joksimović, S., \& Kovanović, V. (2015). Externally-facilitated regulation scaffolding and role assignment to develop cognitive presence in asynchronous online discussions. The Internet and Higher Education, 24, 53-65.

Gerber, S., Scott, L., Clements, D. H., \& Sarama, J. (2005). Instructor influence on reasoned argument in discussion boards. Educational Technology Research and Development, 53(2), 25-39.

Glaser, B. G. (1965). The constant comparative method of qualitative analysis. Social Problems, $12(4), 436-445$.

Graesser, A. C., Person, N. K., \& Hu, X. (2002). Improving comprehension through discourse processing. New directions for teaching and learning, 2002(89), 33-44.

Gumaer, J. (1973). Peer-Facilitated Groupe. Elementary School Guidance \& Counseling, 8(1), 4-11.

Guo, W. G., Chen, Y., Lei, J., Wen, Y. (2014). The effects of facilitating feedback on online learners' cognitive engagement: Evidence from the asynchronous online discussion. Education Science, 4(2), 193-208.

Hakkarainen, K., \& Sintonen, M. (2002). The interrogative model of inquiry and computer-supported collaborative learning. Science \& Education, 11(1), 25-43.

Hara, N. M., Bonk, C. J. M. \& Angeli, C. M. (2000). Content analysis of online discussion in an applied educational psychology course. Instructional Science, 28, 115-152.

Hew, K. F. (2015). Student perceptions of peer versus instructor facilitation of asynchronous online discussions: further findings from three cases. Instructional Science, 43(1), 19-38.

Hew, K. F., \& Cheung, W. S. (2008). Attracting student participation in asynchronous online discussions: A case study of peer facilitation. Computers \& Education, 51, 1111-1124.

Hew, K. F., \& Cheung, W. S. (2011). Higher-level knowledge construction in asynchronous online discussions: An analysis of group size, duration of online discussion, and student facilitation techniques. Instructional Science, 39(3), 303-319.

Hew, K. F., Cheung, W. S., \& Ng, C. S. L. (2010). Student contribution in asynchronous online discussion: A review of the research and empirical exploration. Instructional Science, 38(6), 571-606.

Hiltz. R. S. (1988). Learning in a virtual classroom. Final evaluation report 25, Newark, N.J.: Computerized Conferencing and Communications Centre.

Hmelo-Silver, C. E., \& Barrows, H. S. (2006). Goals and strategies of a problem-based learning facilitator. Interdisciplinary journal of problem-based learning, 1(1), 5-22.

Hmelo-Silver, C. E., \& Barrows, H. S. (2008). Facilitating collaborative knowledge building. Cognition and instruction, 26(1), 48-94.

Hung D., Chen D. \& Cheung W.S. (1998) The PQRS of Scaffolding the Negotiation of Meanings, pp. 1-7. Nanyang Technological University, National Institute of Education, Singapore. Retrieved from: https://repository.nie.edu.sg/bitstream/10497/14894/1/ERA-1998-336 a.pdf

Ioannou, A., Demetriou, S., \& Mama, M. (2014). Exploring factors influencing collaborative knowledge construction in online discussions: Student facilitation and quality of initial postings. American Journal of Distance Education, 28(3), 183-195. 
Kalelioglu, F., \& Gülbahar, Y. (2014). The Effect of Instructional Techniques on Critical Thinking and Critical Thinking Dispositions in Online Discussion. Educational Technology \& Society, 17(1), 248-258.

Kanuka, H., Rourke, L., \& Laflamme, E. (2007). The influence of instructional methods on the quality of online discussion. British Journal of Educational Technology, 38(2), 260-271.

Kear, K. (2004). Peer learning using asynchronous discussion systems in distance education. Open Learning: The Journal of Open, Distance and e-Learning, 19(2), 151-164.

Keles, E. (2018). Use of Facebook for the Community Services Practices course: Community of inquiry as a theoretical framework. Computers \& Education, 116, 203-224.

Kennedy, D. (2004). The role of a facilitator in a community of philosophical inquiry. Metaphilosophy, 35(5), 744-765.

Kennedy, N. S., \& Kennedy, D. (2010). Between chaos and entropy: community of inquiry from a systems perspective. Complicity: An International Journal of Complexity and Education, 7(2).

King, A. (1994). Guiding knowledge construction in the classroom: Effects of teaching children how to question and how to explain. American Educational Research Journal, 31(2), 338-368.

King, A. (1999). Discourse patterns for mediating peer learning. In A. M. O’Donnell \& A. King (Eds.), Cognitive perspectives on peer learning (pp. 87-117). Mahwah, NJ: Erlbaum.

King, A. (2007). Scripting collaborative learning processes: A cognitive perspective. In Scripting computer-supported collaborative learning (pp. 13-37). Springer US.

Kobbe, L., Weinberger, A., Dillenbourg, P., Harrer, A., Hämäläinen, R., Häkkinen, P., \& Fischer, F. (2007). Specifying computer-supported collaboration scripts. International Journal of Computer-Supported Collaborative Learning, 2(2), 211-224.

Koh, J. H. L., Herring, S. C., \& Hew, K. F. (2010). Project-based learning and student knowledge construction during asynchronous online discussion. Internet and Higher Education, 13(4), 284-291.

Koschmann, T., Glenn, P., \& Conlee, M. (1999). Theory presentation and assessment in a problembased learning group. Discourse Processes, 27, 119-133.

Kozan, K., \& Richardson, J. C. (2014). Interrelationships between and among social, teaching, and cognitive presence. The Internet and Higher Education, 21, 68-73.

Krippendorff, K. (2012). Content analysis: An introduction to its methodology. Beverly Hills, CA: Sage.

Lim, C. P., \& Cheah, P. T. (2003). The role of the tutor in asynchronous discussion boards: A case study of a pre-service teacher course. Educational Media International, 40(1-2), 33-48.

Mazzolini, M., \& Maddison, S. (2003). Sage, guide or ghost? The effect of instructor intervention on student participation in online discussion forums. Computers \& Education, 40(3), 237-253.

McKerlich, R., Riis, M., Anderson, T., \& Eastman, B. (2011). Student perceptions of teaching presence, social presence and cognitive presence in a virtual world. Journal of Online Learning and Teaching, 7(3), 324-336.

McLuckie, J., \& Topping, K. J. (2004). Transferable skills for online peer learning. Assessment \& Evaluation in Higher Education, 29(5), 563-584. 
Meyer, K. (2003). Face-to-face versus threaded discussions: the role of time and higher-order thinking. Journal of Asynchronous Learning Networks, 7, 3, 55-65.

Moore, J. D. (1993). What makes human explanations effective. In Proceedings of the fifteenth annual conference of the Cognitive Science Society (pp. 131-136). Hillsdale, New Jersey: Lawrence Erlbaum Associates, Publishers.

Morueta, R. T., López, P. M., Gómez, Á. H., \& Harris, V. W. (2016). Exploring social and cognitive presences in communities of inquiry to perform higher cognitive tasks. The Internet and Higher Education, 31, 122-131.

Ng, C. S. L., Cheung, W. S., \& Hew, K. F. (2010). Scaffolding interaction in asynchronous online discussion through peer facilitation. In C.H. Steel, M.J. Keppell, P. Gerbic \& S. Housego (Eds.), Curriculum, technology \& transformation for an unknown future. Proceedings ascilite Sydney 2010 (pp.690-693). Retrieved from: http://ascilite.org.au/conferences/sydney10/procs/Ngposter.pdf

Ng, C. S., Cheung, W. S., \& Hew, K. F. (2012). Interaction in asynchronous discussion forums: peer facilitation techniques. Journal of Computer Assisted Learning, 28(3), 280-294.

Olesova, L., Slavin, M., \& Lim, J. (2016). Exploring the effect of scripted roles on cognitive presence in asynchronous online discussions. Online Learning, 20(4).

Onah, D. F., Sinclair, J., \& Boyatt, R. (2014). Exploring the use of MOOC discussion forums. In Proceedings of London International Conference on Education (pp. 1-4). LICE.

O'keefe, J., \& Nadel, L. (1978). The hippocampus as a cognitive map. Oxford: Clarendon Press. Retrieved from: http://arizona.openrepository.com/arizona/handle/10150/620894

Pellas, N. \& Kazanidis, I. (2012). Re-thinking a cognitive presence framework for the utilization and transferability of the Jigsaw technique in open source virtual worlds. IEEE Learning Technology Newsletter, 14(3), 24-27.

Poole, D. M. (2000). Student participation in a discussion-oriented online course: A case study. Journal of research on computing in education, 33(2), 162-177.

Popescu, E. (2016). Investigating students' blogging activity in project-based learning settings. In State-of-the-Art and Future Directions of Smart Learning (pp. 145-155). Springer Singapore.

Pressley, M., Wood., E. Woloshyn, V. E., Martin, V., King, A., \& Menke, D. (1992). Encouraging mindful use of prior knowledge: Attempting to construct explanatory answers facilitates learning. Educational Psychologist, 27, 91-109.

Richardson, J. C., \& Ice, P. (2010). Investigating students' level of critical thinking across instructional strategies in online discussions. The Internet and Higher Education, 13(1), 5259.

Rourke, L., \& Anderson, T. (2002). Using peer teams to lead online discussions. Journal of Interactive Media in Education, 1(1), 1-21.

Rovai, A. P. (2007). Facilitating online discussions effectively. The Internet and Higher Education, $10(1), 77-88$.

Roscoe, R. D., \& Chi, M. T. (2007). Understanding tutor learning: Knowledge-building and knowledge-telling in peer tutors' explanations and questions. Review of Educational Research, 77(4), 534-574. 
Roscoe, R. D., \& Chi, M. T. (2008). Tutor learning: The role of explaining and responding to questions. Instructional Science, 36(4), 321-350.

Salmon, G. (2000). A model for CMC in education and training. E-moderating. The key to teaching and learning online. London: Kogan Page.

Schellens, T., Keer, H. V., \& Valcke, M. (2005). The impact of role assignment on knowledge construction in asynchronous discussion groups. Small Group Research, 36(6), 704-745.

Schrire, S. (2006). Knowledge building in asynchronous discussion groups: Going beyond quantitative analysis. Computers \& Education, 46(1), 49-70.

Schwarz, B. B., \& Glassner, A. (2007). The role of floor control and of ontology in argumentative activities with discussion-based tools. International Journal of Computer-Supported Collaborative Learning, 2(4), 449-478.

Seo, K. K. (2007). Utilizing peer moderating in online discussions: Addressing the controversy between teacher moderation and nonmoderation. The American Journal of Distance Education, 21(1), 21-36.

Shea, P., \& Bidjerano, T. (2009). Community of inquiry as a theoretical framework to foster "epistemic engagement" and "cognitive presence" in online education. Computers \& Education, 52(3), 543-553.

Shea, P., Hayes, S., Uzuner-Smith, S., Gozza-Cohen, M., Vickers, J., \& Bidjerano, T. (2014). Reconceptualizing the community of inquiry framework: An exploratory analysis. The Internet and Higher Education, 23, 9-17.

Stein, D. S., Wanstreet, C. E., Glazer, H. R., Engle, C. L., Harris, R. A., Johnston, S. M., ... \& Trinko, L. A. (2007). Creating shared understanding through chats in a community of inquiry. The Internet and Higher Education, 10(2), 103-115.

Stein, D. S., Wanstreet, C. E., Slagle, P., Trinko, L. A., \& Lutz, M. (2013). From 'hello’to higherorder thinking: The effect of coaching and feedback on online chats. The Internet and Higher Education, 16, 78-84.

Sun, Y., Franklin, T., \& Gao, F. (2017). Learning outside of classroom: Exploring the active part of an informal online English learning community in China. British Journal of Educational Technology, 48(1), 57-70.

Taddei, L. M., \& Budhai, S. S. (2016). Using Voice-Recorded Reflections to Increase Cognitive Presence in Hybrid Courses. Journal of Digital Learning in Teacher Education, 32(1), 38-46.

Truong, B. T. (2017, May). Cognitive Presence in Minecraft Online Discussion Forums: How Question Framing Affects Subsequent Discussions. In Proceedings of the 2017 CHI Conference Extended Abstracts on Human Factors in Computing Systems (pp. 190-195). ACM.

Vaughan, N. \& Garrison, D. R. (2005). Creating cognitive presence in a blended faculty development community. The Internet and Higher Education, 8, 1, 1-12.

Walther, J. B. (1996). Computer-mediated communication: impersonal, interpersonal, and hyperpersonal interaction. Communication Research, 23(1), 3-43.

Wang, C. H., \& Shan, S. (2018). the Effects of Self- Efficacy on Learners' Perceptions of Cognitive Presence in Online Collaborative Learning Activities. PEOPLE: International Journal of Social Sciences, 3(3), 1144-1172. 
Weinberger, A., Ertl, B., Fischer, F., \& Mandl, H. (2005). Epistemic and social scripts in computersupported collaborative learning. Instructional Science, 33(1), 1-30.

Wimmer, R., \& Dominick, J. (1997). Mass media research. Cengage Learning.

Wu, W.-C. V., Chen Hsieh, J. S., \& Yang J. C. (2017). Creating an online learning community in a flipped classroom to enhance EFL learners' oral proficiency. Educational Technology \& Society, 20 (2), 142-157

Xie, K., \& Ke, F. (2011). The role of students' motivation in peer - moderated asynchronous online discussions. British Journal of Educational Technology, 42(6), 916-930.

Xie, K., Yu, C., \& Bradshaw, A. C. (2014). Impacts of role assignment and participation in asynchronous discussions in college-level online classes. The Internet and Higher Education, 20, 10-19.

Yang, S. H. (2016). Conceptualizing effective feedback practice through an online community of inquiry. Computers \& Education, 94, 162-177.

Zhang, M., Lundeberg, M., \& Eberhardt, J. (2011). Strategic facilitation of problem-based discussion for teacher professional development. Journal of the Learning Sciences, 20(3), 342-394.

Zhao, N., \& McDougall, D. (2005, October). Cultural factors affecting Chinese students' participation in asynchronous online learning. In E-Learn: World Conference on E-Learning in Corporate, Government, Healthcare, and Higher Education (pp. 2723-2729). Association for the Advancement of Computing in Education (AACE).

Zhao, H., \& Sullivan, K. P. (2017). Teaching presence in computer conferencing learning environments: Effects on interaction, cognition and learning uptake. British Journal of Educational Technology, 48(2), 538-551.

Zhu, X., \& Simon, H. A. (1987). Learning mathematics from examples and by doing. Cognition \& Instruction, 4, 137-166. 